\title{
EMERGING APPLICATIONS OF SOME IMPORTANT NATURAL COMPOUNDS IN THE FIELD OF ONCOLOGY
}

\author{
CRISTIAN SCHEAU, LIVIA GRAȚIELA MIHAI *, IOANA ANCA BĂDĂRĂU, CONSTANTIN \\ CĂRUNTU
}

Department of Physiology, “Carol Davila” University of Medicine and Pharmacy, 050474, Bucharest, Romania

*corresponding author: livia.mihai@umfcd.ro

Manuscript received: May 2020

\begin{abstract}
Cancer is among the leading causes of death worldwide, with several malignancies presenting an increase in their incidence, such as thyroid cancer, hepatocellular carcinoma, skin melanoma, uterine cancer, and oral cavity cancer. Phytochemicals have long been used in various fields of medicine for their properties, and the discovery of anti-tumour, anti-oxidant, and anti-inflammatory effects of some of these substances have prompted their application in the field of oncology. Several in vivo and in vitro studies have demonstrated the effectiveness of some phytochemicals on specific tumour cell lines, revealing their potential role in the complementary treatment of cancer. This paper addresses the anti-tumour and chemopreventive roles of various phytochemicals in malignancies with increasing incidence.
\end{abstract}

\section{Rezumat}

Cancerul este una dintre cele mai frecvente cauze de mortalitate din lume, câteva dintre aceste patologii prezentând creșteri ale incidenței, cum ar fi cancerul tiroidian, carcinomul hepatocelular, melanomul cutanat, cancerul uterin și carcinomul cavităţii orale. Substanțele fitochimice au fost utilizate mult timp în diverse domenii ale medicinei pentru proprietățile lor, iar descoperirea efectelor anti-tumorale, anti-oxidante și anti-inflamatorii ale unora dintre aceste substanțe au încurajat utilizarea acestora în domeniul oncologiei. Unele studii in vivo și in vitro au demonstrat eficiența unor fitochimicale pe anumite linii celulare tumorale, evidențiind rolul lor potențial în tratamentul complementar al cancerului. Această lucrare se referă la rolurile anti-tumorale și chemopreventive ale diverselor fitochimicale în malignitățile cu incidență în creștere.

Keywords: phytochemicals, chemoprevention, oncology

\section{Introduction}

Cancer is among the leading causes of death, and while some progress has been registered in the last years, the population growth, survival rate augmentation, and aging have led to an increase in the prevalence of cancer and a rise in cancer-related deaths worldwide [12]. Exhaustive prevention measures have led to a decrease in the incidence of some malignancies, such as lung and bronchus cancers, while extensive screening protocols and newly available treatments contributed to a decrease in mortality from some cancers such as prostate, urinary bladder and colorectal cancers [10]. However, despite intense efforts, some cancers show increasing prevalence in the last decade for all races and both sexes, with the most prominent increases being noted in cancers of the thyroid gland $(2 \%)$, followed by the liver and intrahepatic bile duct (1.7\%), melanoma of the skin $(1.2 \%)$, uterine cancer $(0.9 \%$, sex-specific rate calculated considering both sexes), and oral cavity and pharynx cancers $(0.6 \%)$ [24]. Phytochemicals are secondary plant metabolites that have demonstrated anti-tumour properties in numerous in vivo and in vitro studies; among the cited chemopreventive effects, the decrease in oxidative stress, apoptosis stimulation, inhibition of the tumoural inflammatory milieu, and the decrease in the expression on several carcinogenic molecules are some of the most effective mechanisms [7, 64, 65, 75]. However, despite their advantages, many medicinal plants with antitumour properties yield toxic effects, especially in vulnerable populations; plants such as Bersama abyssinica show extensive cytotoxic effects and cannot be used in children, while Pelargonium sidoides, Datura stramonium, and Salvia officinalis may cause seizures and are highly hepatotoxic [17].

Natural compounds act on various mechanisms of cancer development and progression and may modulate the intricate processes occurring in the tumour milieu. One of the main features of the tumour microenvironment is hypoxia, which occurs due to the rapid progression of tumour cells limiting the available oxygen [26]. Epithelial to mesenchymal transition (EMT) is the process of phenotype alteration of the tumour cell, implying the loss of polarity and intercellular adhesion properties that favour the migration of tumour cells and the resistance to therapy [46]. Alterations of the interactions between the genes and proteins resulting from their transcription may lead to 
changes in gene functions and ultimately the emergence of cancer cells; epigenetics is an emerging field that may give rise to new and better strategies for the treatment of cancer [55].
This paper aims to thoroughly present the latest advancements in the potential use of phytochemicals in the most common cancers. The type and origin of the phytochemicals referenced in this article are presented in Table I [16, 29, 34, 54].

Table I

The classification and sources of several phytochemicals with anti-tumour roles

\begin{tabular}{|c|c|c|c|c|c|}
\hline Class & Subclass & Member & IUPAC name [1] & Common sources & Reference \\
\hline \multirow{8}{*}{ Polyphenols } & Curcuminoids & Curcumin & $\begin{array}{c}\text { (1E,6E)-1,7-bis(4-hydroxy-3- } \\
\text { methoxyphenyl)hepta-1,6-diene-3,5-dione }\end{array}$ & $\begin{array}{c}\text { Turmeric (Curcuma } \\
\text { longa) } \\
\end{array}$ & {$[42,72,73]$} \\
\hline & Stilbenoids & Resveratrol & $\begin{array}{c}\text { 5-[(E)-2-(4- } \\
\text { hydroxyphenyl)ethenyl]benzene-1,3-diol }\end{array}$ & $\begin{array}{l}\text { Wine (especially red } \\
\text { wine), peanuts, red } \\
\text { grapes }\end{array}$ & $\begin{array}{c}{[3,23,35,} \\
56,67]\end{array}$ \\
\hline & \multirow{3}{*}{ Flavonols } & Quercetin & $\begin{array}{l}\text { 2-(3,4-dihydroxyphenyl)-3,5,7- } \\
\text { trihydroxychromen-4-one }\end{array}$ & $\begin{array}{l}\text { Capers (Capparis } \\
\text { spinosa), radishes, } \\
\text { red onions }\end{array}$ & {$[22,28]$} \\
\hline & & Fisetin & $\begin{array}{l}\text { 2-(3,4-dihydroxyphenyl)-3,7- } \\
\text { dihydroxychromen-4-one }\end{array}$ & $\begin{array}{c}\text { Strawberries, } \\
\text { cucumbers, apples }\end{array}$ & [41] \\
\hline & & Kaempferol & $\begin{array}{c}\text { 3,5,7-trihydroxy-2-(4- } \\
\text { hydroxyphenyl)chromen-4-one }\end{array}$ & Kale, spinach, tea & [28] \\
\hline & Flavones & Luteolin & $\begin{array}{l}\text { 2-(3,4-dihydroxyphenyl)-5,7- } \\
\text { dihydroxychromen-4-one }\end{array}$ & $\begin{array}{l}\text { Dyer's rocket } \\
\text { (Reseda luteola) }\end{array}$ & {$[22,45]$} \\
\hline & \multirow[b]{2}{*}{ Isoflavonoids } & Genistein & $\begin{array}{c}\text { 5,7-dihydroxy-3-(4- } \\
\text { hydroxyphenyl)chromen-4-one }\end{array}$ & $\begin{array}{l}\text { Lupin, soybeans, } \\
\text { fava beans, coffee }\end{array}$ & {$[2,33]$} \\
\hline & & Daidzein & $\begin{array}{l}\text { 7-hydroxy-3-(4-hydroxyphenyl)chromen- } \\
\text { 4-one }\end{array}$ & $\begin{array}{c}\text { Kwao Krua } \\
\text { (Pueraria mirifica), } \\
\text { soybeans } \\
\end{array}$ & {$[33]$} \\
\hline $\begin{array}{l}\text { Organo- } \\
\text { sulphuric }\end{array}$ & Isothiocyanates & Sulforaphane & 1-isothiocyanato-4-methylsulfinylbutane & $\begin{array}{c}\text { Broccoli, cabbage, } \\
\text { Brussels sprouts }\end{array}$ & {$[30]$} \\
\hline Capsaicinoids & - & Capsaicin & $\begin{array}{c}(E)-\mathrm{N}-[(4-h y d r o x y-3- \\
\text { methoxyphenyl)methyl]-8-methylnon-6- } \\
\text { enamide }\end{array}$ & $\begin{array}{l}\text { Chilies (genus } \\
\text { Capsicum) }\end{array}$ & {$[5,25,43]$} \\
\hline Cannabinoids & - & $\begin{array}{l}\text { Cannabidiol } \\
\text { and } \\
\text { THC }\end{array}$ & $\begin{array}{c}\text { 2-[(1R,6R)-3-methyl-6-prop-1-en-2- } \\
\text { ylcyclohex-2-en-1-yl]-5-pentylbenzene- } \\
\text { 1,3-diol } \\
\text { and } \\
\text { 6,6,9-trimethyl-3-pentyl-6a,7,8,10a- } \\
\text { tetrahydrobenzo[c]chromen-1-ol }\end{array}$ & Cannabis & {$[52]$} \\
\hline Terpenes & $\begin{array}{l}\text { Sesquiterpene } \\
\text { lactones }\end{array}$ & Artemisinin & 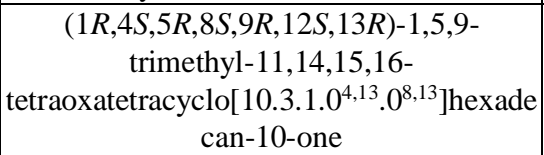 & $\begin{array}{l}\text { Sweet wormwood } \\
\text { (Artemisia annua) }\end{array}$ & [66] \\
\hline Alkaloids & - & Piperine & $\begin{array}{l}\text { (2E,4E)-5-(1,3-benzodioxol-5-yl)-1- } \\
\text { piperidin-1-ylpenta-2,4-dien-1-one }\end{array}$ & Black pepper & [58] \\
\hline
\end{tabular}

\section{Phytochemicals in cancer}

The progress of science and technology has allowed for the adequate assessment of the anti-tumour effects of phytochemicals in various malignancies (Table II). Thyroid cancer

Thyroid cancer is considered a mild form of cancer, with overall low metastasis rates, moderate severity, and relatively effective treatment; however, some histopathologic types such as anaplastic thyroid cancer have low survival rates and high mortality, due to the lack of a suitable treatment $[9,39]$. The thyroid gland's roles in hormone synthesis and the metabolism of iodine add a level of complexity in the curative treatment of cancers. Certain phytochemicals, such as resveratrol, curcumin, quercetin and iso-flavones demonstrate anti-inflammatory, anti-oxidative, and anti-proliferative effects, such as the induction of apoptosis, cell growth restriction and angiogenesis inhibition [18, 57].

Resveratrol is particularly useful as an adjuvant in radioactive iodine therapy for thyroid cancer, as it protects normal cells against toxicity while also sensitizing thyroid cancer cells to ${ }^{131} \mathrm{I}$ [23]. Furthermore, resveratrol can induce apoptosis by increasing several pro-apoptotic factors and can suppress achaete-scute homolog 1 and chromogranin $\mathrm{A}$ in in vitro studies $[56,67]$. 
Table II

Summary of reported effects of various phytochemicals in oncology

\begin{tabular}{|c|c|c|c|c|}
\hline Cancer type & $\begin{array}{l}\text { Natural } \\
\text { compound }\end{array}$ & Antitumoural effect & Study type & References \\
\hline \multirow{8}{*}{ Thyroid cancer } & Resveratrol & $\begin{array}{l}\text { apoptosis induction via MAPK-, p53- } \\
\text {, and Notch2-mediated mechanisms }\end{array}$ & $\begin{array}{l}\text { in vitro (human thyroid cancer cell and } \\
\text { human non-malignant fibroblast cell) }\end{array}$ & {$[23,56,67]$} \\
\hline & \multirow{3}{*}{ Curcumin } & $\begin{array}{c}\begin{array}{c}\text { suppression of EMT and cell } \\
\text { migration }\end{array} \\
\end{array}$ & $\begin{array}{c}\text { in vitro (papillary thyroid cancer cell } \\
\text { line } \mathrm{K} 1 \text { ) }\end{array}$ & {$[72]$} \\
\hline & & $\begin{array}{l}\text { caspase-dependent apoptosis } \\
\text { induction, cell cycle arrest }\end{array}$ & $\begin{array}{c}\text { in vitro (papillary thyroid cancer cell } \\
\text { lined TPC } 1 \text { and BCPAP) }\end{array}$ & {$[42,73]$} \\
\hline & & $\begin{array}{l}\text { decrease in VEGF and TNF- } \alpha \\
\text { expression }\end{array}$ & $\begin{array}{c}\text { in vitro (papillary thyroid cancer cell } \\
\text { lined TPC } 1 \text { ) }\end{array}$ & [42] \\
\hline & \multirow[b]{2}{*}{ Quercetin } & $\begin{array}{l}\text { facilitating apoptosis via heat } \\
\text { sensitization }\end{array}$ & $\begin{array}{c}\text { in vivo (mice bearing human thyroid } \\
\text { cancer cell line TT tumours) }\end{array}$ & [74] \\
\hline & & $\begin{array}{l}\text { promotion of redifferentiation and } \\
\text { tumour growth inhibition }\end{array}$ & $\begin{array}{c}\text { in vitro (papillary and follicular thyroid } \\
\text { cancer cell lines of various } \\
\text { differentiations: TPC-1, FTC-133, } \\
\text { NPA, FRO, ARO) }\end{array}$ & [27] \\
\hline & \multirow[t]{2}{*}{ Genistein } & $\begin{array}{c}\text { inhibition of tumour growth and } \\
\text { invasion via tyrosine kinase } \\
\text { antagonism }\end{array}$ & $\begin{array}{l}\text { in vitro (follicular thyroid cancer cell } \\
\text { line FTC-133) }\end{array}$ & {$[20]$} \\
\hline & & $\begin{array}{l}\text { apoptosis induction, inhibition of cell } \\
\text { proliferation, increase in ROS levels }\end{array}$ & $\begin{array}{l}\text { in vitro (human thyroid cancer cells } \\
\text { SNU 80) }\end{array}$ & {$[2]$} \\
\hline \multirow{4}{*}{$\begin{array}{l}\text { Hepatocellular } \\
\text { carcinoma }\end{array}$} & Resveratrol & $\begin{array}{c}\text { inhibition of proliferation and } \\
\text { invasion, apoptosis induction, cell } \\
\text { cycle regulation }\end{array}$ & $\begin{array}{l}\text { in vitro (human liver cancer cell lines } \\
\text { Hep G2) }\end{array}$ & [3] \\
\hline & Sulforaphane & $\begin{array}{c}\text { enhancement of aflatoxins } \\
\text { detoxification }\end{array}$ & clinical trials & [30] \\
\hline & Curcumin & $\begin{array}{c}\text { tumour development restriction } \\
\text { through inhibition of aflatoxin and } \\
\text { preneoplastic foci } \\
\end{array}$ & $\begin{array}{l}\text { in vivo (male Wistar rats with } \\
\text { aflatoxin-induced carcinogenesis) }\end{array}$ & {$[61]$} \\
\hline & Capsaicin & $\begin{array}{c}\text { ROS-dependent apoptosis induction, } \\
\text { autophagy triggering, angiogenesis } \\
\text { inhibition }\end{array}$ & $\begin{array}{l}\text { in vitro (human liver cancer cell lines } \\
\text { Hep G2) }\end{array}$ & [49] \\
\hline \multirow{6}{*}{$\begin{array}{l}\text { Skin } \\
\text { melanoma }\end{array}$} & Fisetin & $\begin{array}{l}\text { inhibits tumour invasion through } \\
\text { MAPK and NF- } \kappa \mathrm{B} \text { signalling } \\
\text { pathways and promotion of } \\
\text { mesenchymal to epithelial transition }\end{array}$ & $\begin{array}{c}\text { in vitro (human melanoma cells A375, } \\
\text { RPMI-7951 and Hs294T) }\end{array}$ & [41] \\
\hline & \multirow{3}{*}{ Luteolin } & inhibition of EMT & $\begin{array}{l}\text { in vitro and in vivo (murine malignant } \\
\text { melanoma } \mathrm{B} 16 \mathrm{~F} 10 \text { cells) }\end{array}$ & {$[45]$} \\
\hline & & $\begin{array}{l}\text { DNA protective free radical } \\
\text { scavenging potential }\end{array}$ & $\begin{array}{c}\text { in vitro (human melanoma HMB-2 } \\
\text { cells) }\end{array}$ & {$[22]$} \\
\hline & & melanogenesis induction & $\begin{array}{l}\text { in vitro (murine malignant melanoma } \\
\text { B16F10 cells) }\end{array}$ & {$[21]$} \\
\hline & Capsaicin & $\begin{array}{l}\text { tumour growth restriction, apoptosis } \\
\text { induction via multiple mechanisms }\end{array}$ & $\begin{array}{l}\text { in vitro (murine malignant melanoma } \\
\text { B16F10 cells) }\end{array}$ & {$[5,14]$} \\
\hline & $\begin{array}{c}\text { Cannabidiol } \\
\text { and THC }\end{array}$ & apoptosis induction & $\begin{array}{c}\text { in vivo (mice bearing BRAF melanoma } \\
\text { xenografts) }\end{array}$ & {$[52]$} \\
\hline \multirow[t]{2}{*}{ Uterine cancer } & \begin{tabular}{|c|} 
Genistein \\
and daidzein
\end{tabular} & prevention of carcinoma development & \begin{tabular}{|c} 
in vivo (oestrogen-related endometrial \\
carcinogenesis model in \\
ovariectomized mice)
\end{tabular} & [33] \\
\hline & Artemisinin & $\begin{array}{l}\text { cell cycle arrest induction, } \\
\text { antiproliferative effects }\end{array}$ & $\begin{array}{c}\text { in vitro (cultured human Ishikawa } \\
\text { endometrial cancer cells) }\end{array}$ & [66] \\
\hline \multirow[t]{2}{*}{$\begin{array}{l}\text { Oral cavity } \\
\text { cancer }\end{array}$} & $\begin{array}{l}\text { Kaempferol } \\
\text { and } \\
\text { quercetin }\end{array}$ & $\begin{array}{c}\text { caspase-3-dependent apoptosis } \\
\text { induction }\end{array}$ & $\begin{array}{c}\text { in vitro (squamous carcinoma } \\
\text { cell lines originated from retromolar } \\
\text { trigone and lymph nodes of oral cavity } \\
\text { cancer) }\end{array}$ & {$[28]$} \\
\hline & Piperine & $\begin{array}{l}\text { tumour growth inhibition, cell cycle } \\
\text { arrest induction }\end{array}$ & $\begin{array}{c}\text { in vitro (human oral squamous } \\
\text { carcinoma KB cell line) }\end{array}$ & {$[58]$} \\
\hline
\end{tabular}

Curcumin, an active component of turmeric, can reverse the epithelial-mesenchymal transition process involved in metastasis and can decrease the migration of papillary thyroid cancer cells by modulating the 
expression levels of E-Cadherin and matrix metalloproteinase-9 [72]. Additionally, curcumin can modulate the cell metabolic activity vitality, but is also able to induce cell cycle arrest at the G2/M phase and trigger caspase-dependent apoptosis in human papillary thyroid carcinoma cells, in a dose-dependent manner; curcumin anti-inflammatory and anti-oxidant properties were also recorded [42, 73].

Quercetin can inhibit heat shock protein thus augmenting the effects of targeted hyperthermia when used as a therapeutical alternative in thyroid cancer, facilitating apoptosis [74]. Quercetin can also promote the restoration of normal cell markers in cancer-affected cells by inhibiting the expression of CD97 and increasing the sodium-iodine symporter expression [27].

Genistein, an isoflavone, can decrease the concentrations of epidermal growth factor and transforms growth factor-alpha by inhibiting tyrosine kinase, limiting follicular thyroid cancer growth and the in vitro invasion [20]. Moreover, when associated, genistein can increase the apoptosis-inducing efficacy of photodynamic therapy on thyroid cancer cells, inhibiting proliferation and increasing reactive oxygen species (ROS) levels [2].

\section{Hepatocellular carcinoma}

Hepatocellular carcinoma (HCC) is one of the most lethal cancers, with common recurrences after treatment, and relatively difficult to diagnose at small sizes or in particular subtypes $[13,47]$. HCC commonly develops on liver cirrhosis, this disorder adding further complications such as variceal bleeding, ascites, cardiomyopathy, and hepatic encephalopathy $[62,70]$. HCC spread and invasion are favoured by imbalances between matrix metalloproteinases and their tissue inhibitors in the tumour milieu, while tumour progression is promoted by cancer-associated fibroblasts that also impact the targeted therapy [50, 71].

In multiple in vivo and in vitro studies, resveratrol has shown great promise as an anti-tumour and chemopreventive agent in HCC [59]. Resveratrol decreases the proliferation and invasion of liver cancer cells, through various mechanisms such as limiting the ability to enter mitosis, decreasing the expression of vascular endothelial growth factor or causing cell cycle arrest; additionally, resveratrol is toxic to HCC cells, increasing apoptosis and DNA fragmentation and modulating the cell cycle regulation [3].

Sulforaphane is a bioactive phytochemical capable of enhancing nuclear factor erythroid 2-related factor 2 transcription, accumulating a cytoprotective concentration that offers resistance to liver carcinogenesis and is currently undergoing clinical trials to determine if broccoli sprout beverages may determine the detoxification of aflatoxins and impact the incidence of HCC [30]. Curcumin has shown promising results after in vivo and in vitro testing on HCC models, demonstrating the ability to decrease pre-neoplasic foci induced by aflatoxin B1 in rat livers, indicating its potential use in the prevention of HCC occurrence [61].

Capsaicin impacts most of the major pathways involved in the growth and invasion of $\mathrm{HCC}$, through multiple mechanisms, such as inhibiting tumour angiogenesis, generating apoptotic levels of ROS and causing autophagy through hedgehog signalling [25, 49].

Associated hepatic encephalopathy (HE) may imply sensitive imbalances in specific brain metabolites that may be ascertained with advanced imaging methods [51]. Neural viability may supplementary be affected by drugs, neuroendocrine factors, or various substances [36]. Acai frozen pulp can prevent the carbon tetrachloride-induced increase of interleukins (ILs)- $1 \beta$ and -18 , and tumour necrosis factor- $\alpha(\mathrm{TNF}-\alpha)$ in the brain tissue in vivo, potentially contributing to the improvement of $\mathrm{HE}$ and the overall disease status [11]. Minimal hepatic encephalopathy is the infraclinical stage of HE, and can significantly impact patients' quality of life; unfortunately, the diagnosis is difficult and relies on psychometric testing or magnetic resonance spectroscopy [48]. Resveratrol decreases neuroinflammation and exhibits beneficial psychological effects by reducing anxiety and depression in patients with minimal hepatic encephalopathy [35].

\section{Skin melanoma}

Melanoma is a potentially fatal tumour, with high metastatic rates and affecting young and middleaged people [44]. Lymph node involvement is an important prognostic factor in the early stages [32, 68]. Multiple pathways are activated in the process of tumorigenesis, metastasis and therapy resistance and phytochemicals have demonstrated beneficial effects both in the prevention and in the treatment of metastatic melanoma [15, 40, 53, 63].

Fisetin limits melanoma cell invasiveness by modulating mitogen-activated protein kinase/extracellular signalregulated kinase 1/2 (MAPK/ERK) signalling and reducing the activation of nuclear factor-kappa $B$ $(\mathrm{NF}-\kappa \mathrm{B})$ pathway [41]. Moreover, fisetin causes a downregulation in the mammalian target of rapamycin (mTOR) and phosphatidylinositol 3-kinase (PI3K)/ protein kinase $\mathrm{B}$ (AKT) pathways while also promoting mesenchymal to epithelial transition, further evidence of its potential as an anti-tumour agent in melanoma [41]. Luteolin inhibits epithelial-mesenchymal transition though the $\beta 3$ integrin/focal adhesion kinase (FAK) pathway, promotes apoptosis and inhibits melanoma cell growth while also protecting DNA and inducing melanogenesis [6, 21, 22, 45].

Capsaicin can be administered topically and delays tumour growth, inducing melanoma cells apoptosis through various mechanisms such as down-regulation of Bcl-2 and PI3K/AKT pathway, an increase of p53 and activation of caspases 3,8 and 9 [5, 8, 14, 43].

Several cannabinoids, such as cannabidiol and $\Delta^{9}$ tetrahydrocannabinol (THC) have demonstrated in vivo and in vitro anti-tumour properties in melanoma; 
THC induces apoptosis, and its effects are augmented in co-treatment with cannabidiol, which can also enhance the chemotherapeutic effect of cisplatin in melanoma animal models [52].

\section{Uterine cancer}

Uterine cancer is another malignancy with rising incidence and mortality; increased body weight, diabetes and the decrease in menopausal hormonal therapy are contributing factors, and due to the fact that screening tests are not currently recommended, uterine cancer continues to be a major health problem [19]. Two isoflavones, genistein and daidzein are effective in preventing the occurrence of endometrial adenocarcinoma in mice models, through the suppression of cytokines TNF- $\alpha$ and IL- $1 \alpha$ and the suppression of c-fos and c-jun genes that are involved in the expression of activator protein 1, a promoter of cell growth and proliferation [33].

Artemisinin demonstrates anti-proliferative effects in endometrial carcinoma by inducing cell cycle arrest and downregulating cyclin-dependent kinase 4 (CDK4), by disrupting the interactions of $\mathrm{CDK} 4$ promoter with $\mathrm{NF}-\kappa \mathrm{B}[66]$.

Oral cavity cancer

Oral cavity carcinogenesis is a complex process that entails an increase in oncogenes expression and decrease of tumour suppressor genes, promoted by exogenous factors such as viral infections, smoking, or alcohol consumption $[4,31,60]$. The impact of alcohol in the incidence of oral cavity cancers was further studied in regard to phytochemicals present in certain beverages such as wine, and while no correlation was found between the phytochemicals in wine and cancer risk, some authors hypothesized that phytochemicals may balance the negative effects of ethanol on carcinogenesis [69].

Kaempferol and quercetin isolated from Ginkgo biloba can trigger apoptosis in oral cancer cells through a caspase-3 dependent mechanism, successfully inhibiting cell proliferation in a dose-dependent manner [28]. Piperine is a caspase-mediated pro-apoptotic alkaloid that, in high concentrations, can suppress oral squamous cell tumour growth through ROS production increase and mitochondrial depolarization, while also causing cell cycle arrest and nuclear condensation [37, 38, 58].

\section{Conclusions}

Phytochemicals have been used for their pharmaceutical properties since ancient times. The anti-oxidant, antiinflammatory, and anti-carcinogenic properties of different phytochemicals make them good candidates for the complementary treatment of most cancers, including those with rising incidence. The relatively low toxicity and good bioavailability recommend them for the use in oncology, as their effectiveness and safety remains to be tested in future clinical trials.

\section{Acknowledgement}

This research and APC were funded by a grant of the Romanian Ministry of Research and Innovation, CCCDI-UEFISCDI, project number 61PCCDI/2018 PN-III-P1-1.2-PCCDI-2017-0341, within PNCDI-III.

\section{Conflict of interest}

The authors declare no conflict of interest.

\section{References}

1. National Center for Biotechnology Information. PubChem Database, https://pubchem.ncbi.nlm.nih.gov.

2. Ahn JC, Biswas R, Chung PS, Combination with genistein enhances the efficacy of photodynamic therapy against human anaplastic thyroid cancer cells. Lasers Surg Med., 2012; 44(10): 840-849.

3. Bishayee A, Politis T, Darvesh AS, Resveratrol in the chemoprevention and treatment of hepatocellular carcinoma. Cancer Treat Rev., 2010; 36(1): 43-53.

4. Boda D, Neagu M, Constantin C, Voinescu RN, Caruntu C, Zurac S, Spandidos DA, Drakoulis N, Tsoukalas D, Tsatsakis AM, HPV strain distribution in patients with genital warts in a female population sample. Oncol Lett., 2016; 12(3): 1779-1782.

5. Caruntu C, Negrei C, Ilie Ghita M, Caruntu A, Bădărău A, ioan Buraga IB, Boda D, Albu A, Brănişteanu D, Capsaicin, a hot topic in skin pharmacology and physiology. Farmacia, 2015; 63: 487-91.

6. Casagrande F, Darbon JM, Effects of structurally related flavonoids on cell cycle progression of human melanoma cells: regulation of cyclin-dependent kinases CDK2 and CDK1. Biochem Pharmacol., 2001; 61(10): 1205-1215.

7. Chikara S, Nagaprashantha LD, Singhal J, Horne D, Awasthi S, Singhal SS, Oxidative stress and dietary phytochemicals: Role in cancer chemoprevention and treatment. Cancer Lett., 2018; 413: 122-134.

8. Cojocaru V, Cinteza O, Mariana P, Natalita I, Mircioiu $\mathrm{C}$, Development and optimization of new capsaicin microemulsions for topical administration. Farmacia, 2016; 64: 187-193.

9. Cornett WR, Sharma AK, Day TA, Richardson MS, Hoda RS, van Heerden JA, Fernandes JK, Anaplastic thyroid carcinoma: an overview. Curr Oncol Rep., 2007; 9(2): 152-158.

10. Cronin KA, Lake AJ, Scott S, Sherman RL, Noone A-M, Howlader N, Henley SJ, Anderson RN, Firth AU, Ma J, Kohler BA, Jemal A, Annual Report to the Nation on the Status of Cancer, part I: National cancer statistics. Cancer, 2018; 124(13): 2785-2800.

11. de Souza Machado F, Marinho JP, Abujamra AL, Dani C, Quincozes-Santos A, Funchal C, Carbon Tetrachloride Increases the Pro-inflammatory Cytokines Levels in Different Brain Areas of Wistar Rats: The Protective Effect of Acai Frozen Pulp. Neurochem Res., 2015; 40(9): 1976-1983.

12. Dickman PW, Adami HO, Interpreting trends in cancer patient survival. J Intern Med., 2006; 260(2): 103-117.

13. Fujiwara N, Friedman SL, Goossens N, Hoshida Y, Risk factors and prevention of hepatocellular carcinoma 
FARMACIA, 2020, Vol. 68, 6

in the era of precision medicine. J Hepatol., 2018; 68(3): 526-549.

14. Georgescu S-R, Sârbu M-I, Matei C, Ilie MA, Caruntu C, Constantin C, Neagu M, Tampa M, Capsaicin: Friend or Foe in Skin Cancer and Other Related Malignancies?. Nutrients, 2017; 9(12): 1-14.

15. Georgescu SR, Tampa M, Mitran CI, Mitran MI, Caruntu C, Caruntu A, Lupu M, Matei C, Constantin $\mathrm{C}$, Neagu M. Tumour Microenvironment in Skin Carcinogenesis. In: Birbrair A, editor. Tumor Microenvironments in Organs: From the Brain to the Skin Part A. Cham: Springer International Publishing; 2020; 123-142.

16. Gertsch J, Cannabimimetic phytochemicals in the diet - an evolutionary link to food selection and metabolic stress adaptation?. Br J Pharmacol., 2017; 174(11): 1464-1483.

17. Ghorani-Azam A, Sepahi S, Riahi-Zanjani B, Alizadeh Ghamsari A, Mohajeri SA, Balali-Mood M, Plant toxins and acute medicinal plant poisoning in children: A systematic literature review. J Res Med Sci., 2018; 23: 1-9.

18. Guo Y, Effects of curcumin on inhibiting the proliferation of pulmonary artery smooth muscle cells and relieving pulmonary arterial hypertension. Farmacia, 2020; 68: 307-12.

19. Henley SJ, Miller JW, Dowling NF, Benard VB, Richardson LC, Uterine Cancer Incidence and Mortality - United States, 1999-2016. MMWR Morb Mortal Wkly Rep., 2018; 67(48): 1333-1338.

20. Holting T, Siperstein AE, Clark OH, Duh QY, Epidermal growth factor (EGF)- and transforming growth factor alpha-stimulated invasion and growth of follicular thyroid cancer cells can be blocked by antagonism to the EGF receptor and tyrosine kinase in vitro. Eur J Endocrinol., 1995; 132(2): 229-235.

21. Horibe I, Satoh Y, Shiota Y, Kumagai A, Horike N, Takemori H, Uesato S, Sugie S, Obata K, Kawahara $\mathrm{H}$, Nagaoka Y, Induction of melanogenesis by 4'-Omethylated flavonoids in B16F10 melanoma cells. J Nat Med., 2013; 67(4): 705-710.

22. Horvathova K, Chalupa I, Sebova L, Tothova D, Vachalkova A, Protective effect of quercetin and luteolin in human melanoma HMB-2 cells. Mutat Res., 2005; 565(2): 105-112.

23. Hosseinimehr SJ, Hosseini SAH, Resveratrol sensitizes selectively thyroid cancer cell to 131-iodine toxicity. J Toxicol., 2014; 2014: 1-5.

24. Howlader N, Noone A, Krapcho M, Miller D, Brest A, Yu M, SEER Cancer Statistics Review, 1975-2016. [Based on November 2018 SEER data submission, posted to the SEER web site, April 2019]. Bethesda, MD: National Cancer Institute, 2019.

25. Ilie MA, Caruntu C, Tampa M, Georgescu S-R, Matei C, Negrei C, Ion R-M, Constantin C, Neagu M, Boda D, Capsaicin: Physicochemical properties, cutaneous reactions and potential applications in painful and inflammatory conditions. Exp Ther Med., 2019; 18(2): 916-925.

26. Jing X, Yang F, Shao C, Wei K, Xie M, Shen H, Shu $\mathrm{Y}$, Role of hypoxia in cancer therapy by regulating the tumor microenvironment. Mol Cancer., 2019; 18(1): 1-15.
27. Kang HJ, Youn YK, Hong MK, Kim LS, Antiproliferation and redifferentiation in thyroid cancer cell lines by polyphenol phytochemicals. $J$ Korean Med Sci., 2011; 26(7): 893-899.

28. Kang JW, Kim JH, Song K, Kim SH, Yoon JH, Kim KS, Kaempferol and quercetin, components of Ginkgo biloba extract (EGb 761), induce caspase3 -dependent apoptosis in oral cavity cancer cells. Phytother Res., 2010; 24 Suppl 1: S77-82.

29. Kapinova A, Kubatka P, Golubnitschaja O, Kello M, Zubor P, Solar P, Pec M, Dietary phytochemicals in breast cancer research: anticancer effects and potential utility for effective chemoprevention. Environ Health Prev Med., 2018; 23(1): 1-18.

30. Kensler TW, Egner PA, Agyeman AS, Visvanathan K, Groopman JD, Chen J-G, Chen T-Y, Fahey JW, Talalay P, Keap1-nrf2 signaling: a target for cancer prevention by sulforaphane. Top Curr Chem., 2013; 329: 163-177.

31. Kerawala C, Roques T, Jeannon JP, Bisase B, Oral cavity and lip cancer: United Kingdom National Multidisciplinary Guidelines. J Laryngol Otol., 2016; 130(S2): S83-S89.

32. Letca AF, Ungureanu L, Şenilă SC, Grigore LE, Pop Ş, Fechete O, Vesa ŞC, Cosgarea R, Regression and Sentinel Lymph Node Status in Melanoma Progression. Med Sci Monit., 2018; 24: 1359-1365.

33. Lian Z, Niwa K, Tagami K, Hashimoto M, Gao J, Yokoyama Y, Mori H, Tamaya T, Preventive effects of isoflavones, genistein and daidzein, on estradiol17beta-related endometrial carcinogenesis in mice. Jpn J Cancer Res., 2001; 92(7): 726-734.

34. Liskova A, Kubatka P, Samec M, Zubor P, Mlyncek M, Bielik T, Samuel SM, Zulli A, Kwon TK, Büsselberg D, Dietary Phytochemicals Targeting Cancer Stem Cells. Molecules, 2019; 24(5): 1-20.

35. Malaguarnera G, Pennisi M, Bertino G, Motta M, Borzì AM, Vicari E, Bella R, Drago F, Malaguarnera M, Resveratrol in Patients with Minimal Hepatic Encephalopathy. Nutrients, 2018; 10(3): 1-11.

36. Mihai GL, Badarau IA, Scheau C, Papacocea MT, Papacocea IR, Comparative Study of the Dyes Induced Citotoxicity in Cultures of Cerebelar Granular Neurons. Revista De Chimie, 2019; 70(7): 2439-2441.

37. Moraru A, Roşca I, Craciun B, Nicolescu A, Chiriac A, Voicu V, Insights of the antimicrobial activity of Piperine extracted from Piper Nigrum L. Farmacia, 2019; 67(6): 1099-1105.

38. NavaneethaKrishnan S, Rosales JL, Lee KY, ROSMediated Cancer Cell Killing through Dietary Phytochemicals. Oxid Med Cell Longev., 2019; 2019: 1-16.

39. Nikiforov YE, Nikiforova MN, Molecular genetics and diagnosis of thyroid cancer. Nat Rev Endocrinol., 2011; 7(10): 569-580.

40. Pal HC, Hunt KM, Diamond A, Elmets CA, Afaq F, Phytochemicals for the Management of Melanoma. Mini Rev Med Chem., 2016; 16(12): 953-979.

41. Pal HC, Sharma S, Strickland LR, Katiyar SK, Ballestas ME, Athar M, Elmets CA, Afaq F, Fisetin inhibits human melanoma cell invasion through promotion of mesenchymal to epithelial transition and by targeting MAPK and NFKB signaling pathways. PLoS One, 2014; 9(1): 1-13. 
FARMACIA, 2020, Vol. 68, 6

42. Perna A, De Luca A, Adelfi L, Pasquale T, Varriale B, Esposito T, Effects of different extracts of curcumin on TPC1 papillary thyroid cancer cell line. BMC Complement Altern Med., 2018; 18(1): 1-9.

43. Popescu M, Chiutu L, Mircioiu C, Dima Ş, Capsaicin microemulsions: Preparation, characterization and in vitro release study. Farmacia, 2013; 62: 58-68.

44. Rastrelli M, Tropea S, Rossi CR, Alaibac M, Melanoma: epidemiology, risk factors, pathogenesis, diagnosis and classification. In Vivo, 2014; 28(6): 1005-1011.

45. Ruan JS, Liu YP, Zhang L, Yan LG, Fan FT, Shen CS, Wang AY, Zheng SZ, Wang SM, Lu Y, Luteolin reduces the invasive potential of malignant melanoma cells by targeting beta3 integrin and the epithelialmesenchymal transition. Acta Pharmacol Sin., 2012; 33(10): 1325-1331.

46. Santamaria PG, Moreno-Bueno G, Portillo F, Cano A, EMT: Present and future in clinical oncology. Mol Oncol., 2017; 11(7): 718-738.

47. Scheau AE, Scheau C, Lupescu IG, Nodule-in-Nodule Imaging Pattern in Hepatocellular Carcinoma Treated by Transarterial Chemoembolization - a Multiparametric Magnetic Resonance Imaging Study. J Gastrointestin Liver Dis., 2017; 26(4): 387-393.

48. Scheau C, Badarau AI, Ghergus AE, Popa GA, Lupescu IG, Minimal hepatic encephalopathy diagnosis by magnetic resonance spectroscopy. A case report. $J$ Gastrointestin Liver Dis., 2013; 22(4): 455-459.

49. Scheau C, Badarau IA, Caruntu C, Mihai GL, Didilescu AC, Constantin C, Neagu M, Capsaicin: Effects on the Pathogenesis of Hepatocellular Carcinoma. Molecules, 2019; 24(13): 1-17.

50. Scheau C, Badarau IA, Costache R, Caruntu C, Mihai GL, Didilescu AC, Constantin C, Neagu M, The Role of Matrix Metalloproteinases in the EpithelialMesenchymal Transition of Hepatocellular Carcinoma. Anal Cell Pathol (Amst)., 2019; 2019: 1-10.

51. Scheau C, Badarau IA, Lupescu IG, Papacocea IR, Mihai GL, Papacocea MT, Scheau AE, The Pivotal Role of the Glutamate - glutamine Cycle in Minimal Hepatic Encephalopathy An experimental magnetic resonance spectroscopy study. Revista De Chimie, 2019; 70(8): 2959-2962.

52. Scheau C, Badarau IA, Mihai L-G, Scheau A-E, Costache DO, Constantin C, Calina D, Caruntu C, Costache RS, Caruntu A, Cannabinoids in the Pathophysiology of Skin Inflammation. Molecules, 2020; 25(3): 1-23.

53. Sevastre B, Sarpataki O, Stan R, Taulescu M, Sevastre Berghian A, Olah NK, Furtuna F, Hanganu D, Hangan AC, Cenariu M, Baldea I, Anticancer activity of Euonymus europaeus fruits extract on human melanoma cells. Farmacia, 2017; 65: 56-62.

54. Shankar E, Kanwal R, Candamo M, Gupta S, Dietary phytochemicals as epigenetic modifiers in cancer: Promise and challenges. Semin Cancer Biol., 2016; 40-41: 82-99.

55. Sharma S, Kelly TK, Jones PA, Epigenetics in cancer. Carcinogenesis, 2010; 31(1): 27-36.

56. Shih A, Davis FB, Lin HY, Davis PJ, Resveratrol induces apoptosis in thyroid cancer cell lines via a MAPK- and p53-dependent mechanism. J Clin Endocrinol Metab., 2002; 87(3): 1223-1232.
57. Shin H-J, Hwang K-A, Choi K-C, Antitumor Effect of Various Phytochemicals on Diverse Types of Thyroid Cancers. Nutrients, 2019; 11(1): 1-11.

58. Siddiqui S, Ahamad MS, Jafri A, Afzal M, Arshad M, Piperine Triggers Apoptosis of Human Oral Squamous Carcinoma Through Cell Cycle Arrest and Mitochondrial Oxidative Stress. Nutr Cancer., 2017; 69(5): 791-799.

59. Singh S, Singh PP, Roberts LR, Sanchez W, Chemopreventive strategies in hepatocellular carcinoma. Nat Rev Gastroenterol Hepatol., 2014; 11(1): 45-54.

60. Solomon I, Voiculescu VM, Caruntu C, Lupu M, Popa A, Ilie MA, Albulescu R, Caruntu A, Tanase C, Constantin C, Neagu M, Boda D, Neuroendocrine Factors and Head and Neck Squamous Cell Carcinoma: An Affair to Remember. Dis Markers., 2018; 2018: $1-12$.

61. Soni KB, Lahiri M, Chackradeo P, Bhide SV, Kuttan $\mathrm{R}$, Protective effect of food additives on aflatoxininduced mutagenicity and hepatocarcinogenicity. Cancer Lett., 1997; 115(2): 129-133.

62. Sturm L, Rossle M, Schultheiss M, Complications of liver cirrhosis - pharmaceutical versus interventional therapy. Dtsch Med Wochenschr., 2019; 144(18): 1259-1266.

63. Surcel M, Caruntu C, Tampa M, Matei C, Pițuru S, Georgescu SR, Constantin C, Zurac S, Neagu M, Adrenergic modulation of melanoma cells proliferation. Farmacia, 2018; 66: 820-825.

64. Suceveanu AI, Pantea Stoian A, Mazilu L, Voinea F, Hainăroșie R, Diaconu CC, Pițuru S, Nițipir C, Badiu DC, Ceaușu I, Suceveanu AP, Interferon-free therapy is not a trigger for hepatocellular carcinoma in patients with chronic infection with hepatitis $\mathrm{C}$ virus. Farmacia, 2018; 66(5): 904-908.

65. Tampa M, Matei C, Caruntu C, Poteca T, Mihaila D, Paunescu C, Pitigoi G, Georgescu SR, Constantin C, Neagu M, Cellular impedance measurement - Novel method for in vitro investigation of drug efficacy. Farmacia, 2016; 64: 430-434.

66. Tran KQ, Tin AS, Firestone GL, Artemisinin triggers a G1 cell cycle arrest of human Ishikawa endometrial cancer cells and inhibits cyclin-dependent kinase- 4 promoter activity and expression by disrupting nuclear factor- $\mathrm{KB}$ transcriptional signaling. Anticancer Drugs, 2014; 25(3): 270-281.

67. Truong M, Cook MR, Pinchot SN, Kunnimalaiyaan M, Chen H, Resveratrol induces Notch2-mediated apoptosis and suppression of neuroendocrine markers in medullary thyroid cancer. Ann Surg Oncol., 2011; 18(5): 1506-1511.

68. Ungureanu L, Botar Jid C, Candrea E, Cosgarea R, Senila SC, The role of lymph node ultrasound evaluation in melanoma - review of the literature. Med Ultrason., 2016; 18(2): 224-230.

69. Varoni EM, Lodi G, Iriti M, Ethanol versus Phytochemicals in Wine: Oral Cancer Risk in a Light Drinking Perspective. Int J Mol Sci., 2015; 16(8): 17029-17047.

70. Voiosu A, Wiese S, Voiosu T, Bendtsen F, Moller S, Bile acids and cardiovascular function in cirrhosis. Liver Int., 2017; 37(10): 1420-1430.

71. Yin Z, Dong C, Jiang K, Xu Z, Li R, Guo K, Shao S, Wang L, Heterogeneity of cancer-associated 
fibroblasts and roles in the progression, prognosis, and therapy of hepatocellular carcinoma. J Hematol Oncol., 2019; 12(1): 1-9.

72. Zhang CY, Zhang L, Yu HX, Bao JD, Lu RR, Curcumin inhibits the metastasis of K1 papillary thyroid cancer cells via modulating E-cadherin and matrix metalloproteinase-9 expression. Biotechnol Lett., 2013; 35(7): 995-1000.

73. Zhang L, Cheng X, Gao Y, Bao J, Guan H, Lu R, $\mathrm{Yu} \mathrm{H}, \mathrm{Xu} \mathrm{Q}$, Sun Y, Induction of ROS-independent DNA damage by curcumin leads to G2/M cell cycle arrest and apoptosis in human papillary thyroid carcinoma BCPAP cells. Food Funct., 2016; 7(1): 315-325.

74. Zhou L, Zhang M, Fu Q, Li J, Sun H, Targeted near infrared hyperthermia combined with immune stimulation for optimized therapeutic efficacy in thyroid cancer treatment. Oncotarget, 2016; 7(6): 6878-6890.

75. Zubair H, Azim S, Ahmad A, Khan MA, Patel GK, Singh S, Singh AP, Cancer Chemoprevention by Phytochemicals: Nature's Healing Touch. Molecules, 2017; 22(3): 1-24. 